\title{
Mortality in relation to smoking: 40 years' observations on male British doctors
}

\author{
Richard Doll, Richard Peto, Keith Wheatley, Richard Gray, Isabelle Sutherland
}

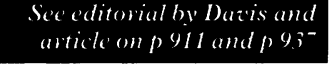

See editorial by Dat's and
article on p 911 and p $93^{-}$

Imperial Cancer Research

Fund Cancer Studies Unit,

Nuffield Department of

Clinical Medicine,

Radcliffe Infirmary, Oxford

OX2 6HE

Richard Doll, honorary

consultant

Richard Peto, professor of

medical statistics

Keith Wheatley, senior

research fellow

Richard Gray, senior research fellow

Isabelle Sutherland, research

assistant

Correspondence to:

Professor Doll.

$B M f$ 1994;309:901-11

\section{Abstract}

Objective-To assess the hazards associated with long term use of tobacco.

Design-Prospective study of mortality in relation to smoking habits assessed in 1951 and again from time to time thereafter, with causes sought of deaths over 40 years (to 1991). Continuation of a study that was last reported after 20 years' follow up (1951-71).

Subjects-34439 British male doctors who replied to a postal questionnaire in 1951 , of whom 10000 had died during the first 20 years and another 10000 have died during the second 20 years.

Results-Excess mortality associated with smoking was about twice as extreme during the second half of the study as it had been during the first half. The death rate ratios during 1971-91 (comparing continuing cigarette smokers with lifelong non-smokers) were approximately threefold at ages 45-64 and twofold at ages 65-84. The excess mortality was chiefly from diseases that can be caused by smoking. Positive associations with smoking were confirmed for death from cancers of the mouth, oesophagus, pharynx, larynx, lung, pancreas, and bladder; from chronic obstructive pulmonary disease and other respiratory diseases; from vascular diseases; from peptic ulcer; and (perhaps because of confounding by personality and alcohol use) from cirrhosis, suicide, and poisoning. A negative association was confirmed with death from Parkinson's disease. Those who stopped smoking before middle age subsequently avoided almost all of the excess risk that they would otherwise have suffered, but even those who stopped smoking in middle age were subsequently at substantially less risk than those who continued to smoke.

Conclusion-Results from the first 20 years of this study, and of other studies at that time, substantially underestimated the hazards of long term use of tobacco. It now seems that about half of all regular cigarettte smokers will eventually be killed by their habit.

\section{Introduction}

After the two large case-control studies of 1950 that showed lung cancer to be closely related to smoking, ${ }^{12}$ prospective studies were needed that could determine which other diseases were also related to the habit. In 1951 all the doctors in Britain were asked what they smoked. Most of the 40000 who replied were male, and a prospective study was started of the causes of death that subsequently occurred among them. The early results confirmed the strong relation between smoking and death from lung cancer, ${ }^{3}$ and found that smoking was also related to mortality from many other diseases. ${ }^{4-6}$ Deaths have continued to be recorded and, from time to time, further questionnaires have been sent to the survivors. The last report on these men was of the results after 20 years. ${ }^{6}$ We now report the results of following them for 40 years to 1991 and compare the apparent effects of cigarette smoking on mortality from all causes during the first and during the second halves of the study. We report also the mortality during the entire 40 year period from 48 specific causes of death, or groups of causes, in men with different smoking habits, and the effects of stopping smoking at different ages, and we discuss the extent to which the effects of smoking on certain causes of death are positively or negatively confounded by the effects of alcohol.

The hazards of tobacco have been documented by many other studies, which have been summarised by the Royal College of Physicians, ${ }^{78}$ the United States Surgeon General, ${ }^{9-11}$ and the International Agency for Research on Cancer. ${ }^{12}{ }^{13}$ Some prospective studies have been far larger than ours; ours, however, has been continued for more than twice as long as any other, which gives it some special interest, for long continued cigarette use is particularly hazardous, ${ }^{14-16}$ and cigarette use by young men became widespread earlier in Britain than in most other countries. During the first half (1951-71) of this study, therefore, the lung cancer rates in middle aged men were higher in Britian than anywhere else in the world, and during the second half (1971-91), the lung cancer rates in men in old age in Britain were among the highest. Hence, a study of smoking and death among British men during these years may be particularly informative about the hazards of long continued cigarette use.

\section{Methods}

QUESTIONNAIRES

At the end of October 1951, questionnaires were sent to all the men and women whose names were on the British medical register and who resided in the United Kingdom. Simple questions were asked about their smoking habits, and replies sufficiently complete to be used were received from 6194 women and 34439 men. When last reported, ${ }^{6}$ one woman had been mistakenly classified as male, until diagnosed as dying of uterine cancer. The relatively few female smokers had not, in general, smoked as long or as intensively as the male smokers, so that they do not provide direct information about the effects of long term smoking. ${ }^{14}$ The present report is therefore restricted to the 40 year follow up of the men. Inquiries about changes in smoking habits and some further details about them were made of the men in 1957, 1966, 1972, 1978, and 1990; on the last two occasions, inquiries were also made about alcohol consumption and some other personal characteristics. Detailed accounts of the questions asked and of the response rates to the earlier questionnaires have been given previously. ${ }^{35617}$ Replies to our last questionnaire, which was sent out at the start of the 40th year of the study, were received from 10807 
(94\% of those not known to have died), and information was obtained about changes in their smoking and drinking habits, their use of aspirin, and the previous occurrence of any vascular disease.

FOLLOW UP

In 1971, information was obtained about the vita status and place of residence of $99.7 \%$ of the men who had responded to the 1951 questionnaire; 10074 were known to have died and 2459 to be living abroad. Those who lived abroad have not been followed since, nor have 218 others $(1 \%$ of those not known to have died) if they then asked to be excluded from the study (102); if they had been struck off the medical register for unprofessional conduct (15); or if, before November 1971, contact with them had been lost (101). Of the remainder, 10449 are known to have died before 1 November $1991 ; 118$ have been censored at the date they were last known to be alive (71 known to have emigrated and 47 with whom contact has been lost); 10615 replied to our questionnaire after 1 November 1990 and are thought to have been alive a year later; and 506 who did not reply to the questionnaire were traced alive after 1 November 1991.

Deaths have been monitored in several overlapping ways. The Office of Population Censuses and Surveys was to notify us automatically when members of the cohort died in Britain. In addition, we monitored the obituary columns of the $B M \mathcal{F}$ and the Medical Directory, and we corresponded directly with the doctors themselves, with people who lived at their last known addresses, or with others who knew them. Our final round of correspondence began in November 1990, so some of the deaths that occurred in the 40th year of the study (November 1990 to October 1991) will have been missed. Judged by the number at risk at the start of this final year (11652), the crude death rate in that year $(489 / 11652=4 \cdot 20 / 1000)$, and the death rates in the previous four years when standardised to the age distribution of the 1990 survivors $(4.61,4.61,4.65$, $4 \cdot 71$; mean $=1 \cdot 1 \times 4 \cdot 20$ ), the death rate in the final year should have been about $10 \%$ higher than we recorded (yielding about 543 deaths instead of 489). The deficiency has, therefore, been allowed for, when necessary, by multiplying the mortality recorded in the last year by $1 \cdot 1$.

\section{CAUSES OF DEATH}

For the vast majority of deaths, including many of those that occurred abroad, information about the underlying cause was obtained from official death certificates. In other instances, when no official information could be obtained, the cause was given in an obituary or described by a relative. In 217 instances ( $1 \%$ of all deaths) the cause remains unknown, commonly because the death occurred in a country in which information about the medical cause of death is not publicly available. Causes were classified according to the seventh revision of the International Classification of Diseases ${ }^{18}$ if the death occurred during the first 27 years (1951-1978) and according to the ninth revision of the international classification ${ }^{19}$ if it occurred during the last 13 years (1 November 1978 to 1991). Special inquiry was made about the evidence for any deaths attributed to lung cancer in the first half of the study, but this rarely led to revision of the diagnosis, ${ }^{6}$ and the certified causes are used for the present analysis. Exceptionally, deaths attributed to pleural mesothelioma were always separated from lung cancer and a special category was created for deaths that were thought likely to be due to pulmonary heart disease (see below).

\section{STATISTICAL METHODS}

In calculating death rates for different categories of smokers we have assumed that questionnaires were returned soon after they were sent out (as the great majority were). Deaths that occurred in the year that a repeat questionnaire was sent out were related to the reply to the previous questionnaire. (This helps limit the effects of disease on smoking.) Otherwise nonsmokers and continuing smokers were analysed in the category in which they last described themselves. The same is true for former smokers, except that they were classed as having stopped smoking for progressively longer periods as each year passed. The mortality attributed to continuing smokers has therefore been slightly attenuated by including with the deaths and the person years at risk some deaths and some years at risk when the individuals had recently become former smokers. Although in principle the mortality among non-smokers might likewise have been slightly increased by including with the non-smokers a few individuals who had recently become smokers, in practice the distortion will be negligible, as the proportion of non-smokers in 1951 who subsequently started smoking is small (see below), most of those who did start soon stopped, and the life threatening effects of smoking generally take many years to appear.

Mortality has been calculated separately for (i) lifelong non-smokers (that is, men who have never reported having smoked as much as one cigarette or $1 \mathrm{~g}$ of tobacco a day for as long as one year) and for men who, to the best of our knowledge, have habitually smoked (ii) only cigarettes, (iii) only pipes or cigars, or (iv) at times both cigarettes and tobacco in other forms. All analyses of non-smokers and of smokers refer to these categories, except where categories (iii) and (iv) have been combined as "other smokers." It is probable, however, that some of the men described as smoking only cigarettes in 1951, particularly those in the older age groups, may have smoked pipes or cigars at an earlier period, as inquiries about the way tobacco was smoked previously were not made until 1957 and were then made only of men smoking pipes or cigars in 1951. Consequently, men classified as smokers only of cigarettes during the second half of the study may have had more prolonged cigarette use (and hence greater hazard) than men of similar age who were similarly classified during the first year.

All mortality rates have been standardised for age and calendar period by calculating the number of deaths that would have been expected in each five year age group and each calendar year in each smoking category if the smoking habit had had no effect on mortality, summing the corresponding observed and expected numbers, and multiplying the ratio of the two numbers by the total death rate for the ages and period covered. Where differences are said to be "nonsignificant" this implies that the two sided $P$ value is greater than 0.05 , without any adjustment for the multiplicity of comparisons.

\section{Results}

CHANGES IN SMOKING HABITS

The smoking habits of those who replied in 1951 and survived to the end of 1990 are contrasted, in table I, with the smoking habits of these subjects about 40 years later. Partly because of the disproportionate attrition of the smokers, but chiefly because most doctors who smoked in 1951 had ceased to do so, the overall proportion of smokers among these 40 year survivors was reduced from $62 \%$ to $18 \%$, the proportion of cigarette smokers was reduced from $53 \%$ to $7 \%$, and the proportion of smokers of cigarettes only (that is, who were not also smoking cigars or pipes) was reduced from $41 \%$ to $6 \%$. These changes were not simply an accompaniment of aging, as they were much greater than the differences seen in 1951 between one 
TABLE I-Smoking habits of doctors who replied to 1951 and 1990-1 questionnaires. Values are numbers (percentages)

\begin{tabular}{|c|c|c|c|c|c|c|}
\hline \multirow[b]{2}{*}{ Smoking habit } & \multirow{2}{*}{$\begin{array}{l}\text { Non- } \\
\text { smoker, } \\
1990-1\end{array}$} & \multirow{2}{*}{$\begin{array}{c}\text { Former } \\
\text { smoker, } \\
1990-1\end{array}$} & \multicolumn{3}{|c|}{ Current smoker, $1990-1^{\star}$} & \multirow[b]{2}{*}{$\begin{array}{c}\text { All habits, } \\
1951\end{array}$} \\
\hline & & & $\begin{array}{c}\text { Cigarette } \\
\text { only }\end{array}$ & $\begin{array}{l}\text { Cigarette } \\
\text { and other }\end{array}$ & $\begin{array}{c}\text { Pipe or } \\
\text { cigar }\end{array}$ & \\
\hline Non-smoker, 1951 & 2361 & 198 & 17 & 4 & 86 & $2666(25)$ \\
\hline Former smoker, 1951 & 0 & 1374 & 10 & 3 & 66 & $1453(13)$ \\
\hline \multicolumn{7}{|l|}{ Current smoker, 1951* } \\
\hline Cigarettes only & 0 & 3355 & 535 & 47 & 446 & $4383(41)$ \\
\hline Cigarettes and other & 0 & 897 & 74 & 31 & 308 & $1310(12)$ \\
\hline Pipe or cigar & 0 & 695 & 16 & 2 & 287 & $1000(9)$ \\
\hline All habits & $2361(22)$ & $6519(60)$ & $652(6)$ & $87(1)$ & 1193 & $10812+(100)$ \\
\hline
\end{tabular}

*As defined in response to respective questionnaires; apart from the distinction between non-smokers (who, by definition, had never smroked regularly) and former smokers, these do not take account of past habits.

tIncluding 197 men who replied but died later in the 40th year of the study.

TABLE II-Change in amount smoked with age (cigarette smokers)

Average No of cigarettes smoked daily: men who currently smoked only cigarettes in 1951 and

\begin{tabular}{lcc} 
& \multicolumn{2}{c}{1971} \\
\cline { 2 - 3 } $\begin{array}{l}\text { Age } \\
\text { (years) }\end{array}$ & 1951 & 1971 \\
\hline $35-44$ & $16 \cdot 9$ & \\
$45-54$ & $19 \cdot 3$ & $18 \cdot 2$ \\
$55-64$ & $19 \cdot 7$ & $19 \cdot 1$ \\
$65-74$ & $18 \cdot 2$ & $18 \cdot 6$ \\
$75-84$ & $14 \cdot 7$ & $16 \cdot 6$ \\
$\geqslant 85$ & $10 \cdot 6$ & $14 \cdot 4$ \\
\hline
\end{tabular}

age group and another (as is shown in table II), and occurred to much the same extent in each age group in 1951: for example, the proportion who smoked cigarettes only was reduced from $37 \%$ to $5 \%$ in men initially under 25 years of age and from $33 \%$ to $2 \%$ in men initially aged 45 years or more. Among the nonsmokers in 1951 who replied in $1990,11 \%$ had started smoking at some time during the intervening 40 years but most $(65 \%)$ had subsequently stopped, and four fifths of those who had continued smoked only pipes or cigars in 1990. Similarly, very few of those who were former smokers in 1951 had started again and continued to smoke in 1990; again, of the 5\% who did, almost all smoked only pipes or cigars. It cannot be assumed, however, that these changes are typical of all male doctors of the same ages, as only two thirds of the doctors in the United Kingdom responded to our 1951 questionnaire, those who did so smoked somewhat less than the non-respondents in $1951,{ }^{5}$ and the knowledge that they were the subjects of a study of the fatal effects of tobacco may itself have influenced their habits over the next 40 years. Those who did smoke cigarettes reported smoking much the same amount at each age at the beginning of both the first and second halves of the study (table II).

\section{MORTALITY BY SMOKING HABIT AND CAUSE}

Pipe and cigar smokers who had never regularly smoked cigarettes have been examined previously. ${ }^{\circ}$ Their mortality from the causes that were classified as closely related to smoking (cancers of the lung, other respiratory sites, and oesophagus; chronic obstructive lung disease; pulmonary tuberculosis; pulmonary heart disease; non-syphilitic aortic aneurysm; hernia) was found to be less than in cigarette smokers, though greater than in non-smokers, while their mortality from other causes was similar to that in non-smokers. For simplicity, we now present mortality rates in detail only for cigarette smokers who had not also regularly smoked tobacco in other forms and have grouped the remaining smokers together as "other current smokers" or "other former smokers."

Mortality rates have been analysed separately for 54 specific causes of death, or groups of causes, and for a 55th group comprising those deaths for which we were unable to discover a cause. They are shown by smoking habit in tables III-V for all the 48 causes or groups of causes that were individually responsible for more than 50 deaths.

Table III shows the rates for 17 types of cancer. Because of the paucity of numbers for some individual types, we have grouped together cancers of the mouth (other than the salivary glands), pharynx (other then the nasopharynx), and larynx, all of which were regarded by the International Agency for Research on Cancer ${ }^{12}$ as diseases that can be caused by smoking, into one group of "upper respiratory cancers." These, together with four of the five other types regarded by the agency as able to be caused by smoking (cancers of the lung, oesophagus, bladder, and pancreas) were in the present study all clearly related to smoking. Three types (cancers of the upper respiratory sites, lung, and oesophagus) were particularly closely related, with the mortality in heavy cigarette smokers at least 15 times that in non-smokers; two other types (cancers of the bladder and pancreas) were about three times more common in heavy cigarette smokers than in nonsmokers. Too few deaths (nine) were specifically attributed to cancer of the renal pelvis (the remaining type regarded by the agency as able to be caused by smoking) for useful analysis. Several studies have suggested that four other types of cancer, which in our study each caused more than $\mathbf{5 0}$ deaths, might sometimes be caused by smoking. One (cancer of the stomach) showed a statistically significant relation with smoking, and another (myeloid leukaemia) showed a marginally significant relation with the amount smoked. The two others (cancer of the kidney, which includes here renal pelvis, and cancer of the liver) showed, in this study, a weak positive and nonsignificant relation with smoking. Six of the other seven specified types of cancer that we examined also TABLE II-Mortality by smoking habits from neoplastic diseases

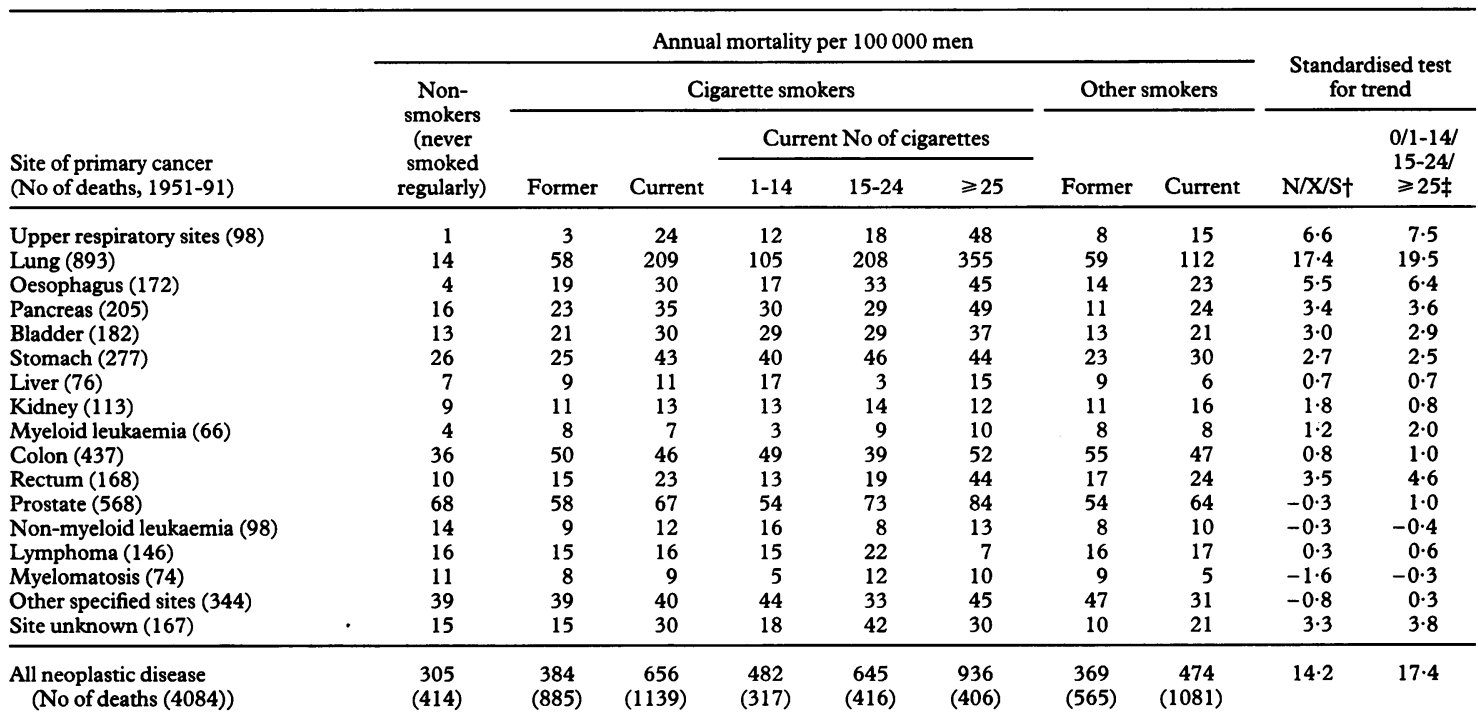

If smoking is unrelated to mortality from a particular disease the standardised trend test has expectation zero and a standard deviation of unity, so values If smoking is unrelated to mortality from a particular disease the standardised trend 
showed no significant relation (cancers of the colon and prostate, lymphomas, multiple myeloma, other leukaemias, and a group of all other specified types of cancer), but the seventh (cancer of the rectum) did, as it had done in our previous report. ${ }^{6}$ A moderate but statistically significant relation was observed for cancers of unknown origin, as was to be expected, as a proportion of them is likely to have arisen in the lung.

Table IV shows mortality similarly divided for 18 diseases (or groups of diseases) of the respiratory and circulatory systems; respiratory tuberculosis is included here rather than with infections. Chronic obstructive lung disease (with which are classed all deaths attributed to "chronic bronchitis" or "emphysema") shows a relation almost as strong as that for cancer of the lung. Pulmonary tuberculosis continues to show a moderately close relation with smoking, but includes data for only nine more deaths than were recorded in the first 20 years of the study. A weak but statistically highly significant relation with smoking was observed for pneumonia, which was much the same at all ages, possibly because of an increased risk associated with the presence of chronic obstructive lung disease. Although this relation is weak it is of some importance because of the substantial number of deaths attributed to pneumonia (4\% of the total). The lack of a clear relation of current tobacco use with death from asthma is not inconsistent with the belief that smoking aggravates the disease. Asthma mortality in all who had ever been smokers (combining current and former smokers) was more than double that in non-smokers (8.3 against 3.7 per 100000 per year), and the relatively high rate in former smokers suggests that the development of potentially life threatening asthma caused many smokers to stop smoking, but they still remained at somewhat increased risk of death from the disease.

Pulmonary heart disease was the circulatory cause of death that was most closely related to smoking, which is hardly surprising. (We have included in this category deaths attributed to myocardial degeneration and congestive heart failure that were associated with chronic obstructive lung disease as well as the few deaths specifically certified as due to pulmonary heart disease.) Next most closely related was aortic aneurysm, with the mortality in heavy cigarette smokers more than five times that in non-smokers. Peripheral vascular disease is another important vascular condition that can be caused by smoking, but although it causes a great deal of disability, it rarely causes loss of life. In this study the number of deaths attributed to it (28) was under 50, and hence did not justify a separate table entry. (But, although based on small numbers, the mortality from this disease among continuing cigarette smokers was four times that in non-smokers and three times that in former cigarette smokers.)

The relatively weak proportional relation observed for the common vascular diseases, ischaemic heart disease, myocardial degeneration (a condition that is being diagnosed much less often now than in the first 20 years of the study; the category includes all deaths classified as No 422 in ICD-7 or 429 in ICD-9), and for the various forms of cerebrovascular disease belie their absolute importance, particularly in middle age. Although the overall mortality in even the heaviest cigarette smokers (25 or more a day) was only about twice that in non-smokers, this ratio is more extreme in middle than in old age and the great number of deaths attributed to vascular causes (more than half of the total) means that the absolute excess mortality from vascular diseases in cigarette smokers was more than double that attributed to the cancers of the respiratory and upper digestive tracts that are so much more closely related to smoking. Of all the categories of vascular disease examined, only two minor categories (rheumatic heart disease and venous thrombosis) and the heterogeneous group of "other cardiovascular diseases" bore no significant relation to smoking.

Table $\mathrm{V}$ shows similar data for 13 other causes of death and for unknown causes. Two conditions stand out: cirrhosis of the liver, for which the mortality was five times as great in continuing cigarette smokers as in non-smokers, and five times as great in heavy as in light cigarette smokers, and peptic ulcer, for which the corresponding excesses were each about threefold. Both these conditions were highly significantly related to smoking $(P<0.001)$. Seven of the other categories also showed higher mortality rates in cigarette smokers than in non-smokers and in heavy cigarette smokers than in light, but the relation with smoking was clearly significant only for a heterogeneous group of "all other

TABLE IV—Mortality by smoking habits from respiratory and vascular diseases

\begin{tabular}{|c|c|c|c|c|c|c|c|c|c|c|}
\hline \multirow{4}{*}{$\begin{array}{l}\text { Type of disease } \\
\text { No of deaths, 1951-91) }\end{array}$} & \multicolumn{8}{|c|}{ Annual mortality per 100000 men } & \multirow{2}{*}{\multicolumn{2}{|c|}{$\begin{array}{l}\text { Standardised test } \\
\text { for trend }\end{array}$}} \\
\hline & \multirow{3}{*}{$\begin{array}{l}\text { Non- } \\
\text { smokers } \\
\text { (never } \\
\text { smoked } \\
\text { regularly) }\end{array}$} & \multicolumn{5}{|c|}{ Cigarette smokers } & \multicolumn{2}{|c|}{ Other smokers } & & \\
\hline & & \multirow[b]{2}{*}{ Former } & \multirow[b]{2}{*}{ Current } & \multicolumn{3}{|c|}{ Current No of cigarettes } & \multirow[b]{2}{*}{ Former } & \multirow[b]{2}{*}{ Current } & \multirow[b]{2}{*}{$\mathrm{N} / \mathrm{X} / \mathrm{S}+$} & \multirow{2}{*}{$\begin{array}{c}0 / 1-14 \\
15-24 \\
\geqslant 25 \ddagger\end{array}$} \\
\hline & & & & $1-14$ & $15-24$ & $\geqslant 25$ & & & & \\
\hline Pulmonary tuberculosis (66) & 4 & 8 & 11 & 7 & 9 & 20 & 8 & 4 & $1 \cdot 1$ & $3 \cdot 7$ \\
\hline Chronic obstructive lung disease (542) & 10 & 57 & 127 & 86 & 112 & 225 & 40 & 51 & $9 \cdot 9$ & $14 \cdot 2$ \\
\hline Pneumonia (864) & 71 & 90 & 138 & 113 & 154 & 169 & 94 & 85 & $3 \cdot 3$ & $5 \cdot 6$ \\
\hline Asthma (70) & 4 & 11 & 7 & 6 & 8 & 6 & 9 & 7 & $0 \cdot 4$ & $1 \cdot 4$ \\
\hline Other respiratory disease (216) & 19 & 28 & 30 & 26 & 31 & 33 & 24 & 18 & $0 \cdot 1$ & $2 \cdot 1$ \\
\hline $\begin{array}{l}\text { All respiratory disease } \\
\text { (No of deaths 1758) }\end{array}$ & $\begin{array}{c}107 \\
(131)\end{array}$ & $\begin{array}{c}192 \\
(455)\end{array}$ & $\begin{array}{c}313 \\
(490)\end{array}$ & $\begin{array}{r}237 \\
(161)\end{array}$ & $\begin{array}{c}310 \\
(170)\end{array}$ & $\begin{array}{c}471 \\
(159)\end{array}$ & $\begin{array}{l}176 \\
(290)\end{array}$ & $\begin{array}{c}164 \\
(392)\end{array}$ & $8 \cdot 2$ & $14 \cdot 2$ \\
\hline Pulmonary heart disease (64) & 0 & 7 & 10 & 5 & 10 & 21 & 3 & 10 & $3 \cdot 7$ & $4 \cdot 2$ \\
\hline Ischaemic heart disease (6438) & 572 & 678 & 892 & 802 & 892 & 1025 & 676 & 653 & $7 \cdot 5$ & $10 \cdot 8$ \\
\hline Myocardial degeneration (841) & 61 & 88 & 125 & 122 & 109 & 173 & 96 & 85 & 3.5 & $5 \cdot 4$ \\
\hline Aortic aneurysm (331) & 15 & 33 & 62 & 38 & 74 & 81 & 22 & 43 & 6.9 & $7 \cdot 0$ \\
\hline Arteriosclerosis (232) & 22 & 18 & 40 & 31 & 38 & 72 & 28 & 23 & 1.9 & 3.8 \\
\hline Hypertension (330) & 32 & 33 & 44 & 28 & 51 & 60 & 37 & 33 & $1 \cdot 1$ & $3 \cdot 0$ \\
\hline Cerebral thrombosis (956) & 93 & 95 & 122 & 93 & 150 & 143 & 100 & 106 & $2 \cdot 4$ & 3.9 \\
\hline Cerebral haemorrhage (607) & 59 & 63 & 81 & 74 & 81 & 92 & 69 & 58 & $1 \cdot 0$ & $2 \cdot 6$ \\
\hline Subarachnoid haemorrhage (82) & 7 & 10 & 15 & 10 & 12 & 24 & 4 & 6 & $1 \cdot 4$ & $3 \cdot 4$ \\
\hline Other cerebrovascular disease (1025) & 94 & 110 & 164 & 167 & 145 & 188 & 101 & 103 & $3 \cdot 2$ & $5 \cdot 0$ \\
\hline Venous thrombosis (103) & 9 & 11 & 14 & 17 & 11 & 14 & 13 & 9 & 0.5 & 0.6 \\
\hline Rheumatic heart disease (125) & 15 & 10 & 15 & 15 & 20 & 8 & 17 & 13 & $-0 \cdot 1$ & -0.5 \\
\hline Other cardiovascular disease (575) & 58 & 63 & 71 & 60 & 82 & 74 & 62 & 59 & 0.7 & 1.5 \\
\hline $\begin{array}{l}\text { All vascular deaths } \\
\text { (No of deaths } 11 \text { 709) }\end{array}$ & $\begin{array}{c}1037 \\
(1304)\end{array}$ & $\begin{array}{c}1221 \\
(2761)\end{array}$ & $\begin{array}{c}1643 \\
(2870)\end{array}$ & $\begin{array}{c}1447 \\
(1026)\end{array}$ & $\begin{array}{c}1671 \\
(1045)\end{array}$ & $\begin{array}{l}1938 \\
(799)\end{array}$ & $\begin{array}{c}1226 \\
(1878)\end{array}$ & $\begin{array}{c}1201 \\
(2986)\end{array}$ & $10 \cdot 5$ & $15 \cdot 7$ \\
\hline
\end{tabular}

If smoking is unrelated to mortality from a particular disease the standardised trend test has expectation zero and a standard deviation of unity, so values above $1 \cdot 96,2 \cdot 57$, and $3 \cdot 29$ correspond to $P$ values (two tailed) of $0 \cdot 05,0 \cdot 01$, and $0 \cdot 001$.

$+\mathrm{N} / \mathrm{X} / \mathrm{S}=$ non-smokers, former smokers of any type of tobacco, current smokers of any type.

$\ddagger 0 / 1-14 / 15-24 / \geqslant 25=$ non-smokers, smokers of $1-14,15-24$, and 25 or more cigarettes only. 


\begin{tabular}{|c|c|c|c|c|c|c|c|c|c|c|}
\hline \multirow{4}{*}{$\begin{array}{l}\text { Type of disease } \\
\text { (No of deaths, 1951-91) }\end{array}$} & \multicolumn{8}{|c|}{ Annual mortality per $100000 \mathrm{men}$} & \multirow{2}{*}{\multicolumn{2}{|c|}{$\begin{array}{l}\text { Standardised test } \\
\text { for trend }\end{array}$}} \\
\hline & \multirow{3}{*}{$\begin{array}{l}\text { Non- } \\
\text { smokers } \\
\text { (never } \\
\text { smoked } \\
\text { regularly) }\end{array}$} & \multicolumn{5}{|c|}{ Cigarette smokers } & \multicolumn{2}{|c|}{ Other smokers } & & \\
\hline & & \multirow[b]{2}{*}{ Former } & \multirow[b]{2}{*}{ Current } & \multicolumn{3}{|c|}{ Current No of cigarettes } & \multirow[b]{2}{*}{ Former } & \multirow[b]{2}{*}{ Current } & \multirow[b]{2}{*}{$\mathrm{N} / \mathrm{X} / \mathrm{S}+$} & \multirow{2}{*}{$\begin{array}{l}0 / 1-14 / \\
15-24 / \\
\geqslant 25 \ddagger\end{array}$} \\
\hline & & & & $1-14$ & $15-24$ & $\geqslant 25$ & & & & \\
\hline Peptic ulcer (134) & 8 & 12 & 24 & 11 & 33 & 34 & 12 & 15 & $3 \cdot 4$ & $4 \cdot 3$ \\
\hline Cirrhosis of liver (160) & 6 & 15 & 32 & 13 & 22 & 68 & 14 & 16 & $5 \cdot 0$ & $8 \cdot 2$ \\
\hline Other digestive disease (298) & 25 & 32 & 43 & 38 & 47 & 47 & 28 & 32 & $2 \cdot 2$ & $2 \cdot 4$ \\
\hline Nephritis (151) & 16 & 13 & 24 & 21 & 27 & 25 & 15 & 14 & $1 \cdot 1$ & 1.7 \\
\hline Other genitourinary disease (212) & 23 & 19 & 32 & 32 & 31 & 36 & 29 & 17 & $-0 \cdot 1$ & $1 \cdot 0$ \\
\hline Parkinsonism (152) & 20 & 22 & 15 & 22 & 6 & 18 & 18 & 8 & $-3 \cdot 1$ & $-1 \cdot 2$ \\
\hline Dementia $(100)$ & 9 & 10 & 16 & 18 & 21 & 4 & 14 & 7 & $0 \cdot 1$ & 0.8 \\
\hline Other diseases (724) & 64 & 79 & 98 & 89 & 90 & 124 & 81 & 72 & $2 \cdot 0$ & 3.9 \\
\hline $\begin{array}{l}\text { All medical causes except neoplastic, } \\
\text { respiratory, or vascular } \\
\text { (No of deaths 1931) }\end{array}$ & $\begin{array}{c}170 \\
(225) \\
\end{array}$ & $\begin{array}{c}202 \\
(458) \\
\end{array}$ & $\begin{array}{c}286 \\
(489) \\
\end{array}$ & $\begin{array}{c}242 \\
(169) \\
\end{array}$ & $\begin{array}{c}277 \\
(171) \\
\end{array}$ & $\begin{array}{c}382 \\
(149) \\
\end{array}$ & $\begin{array}{c}212 \\
(330) \\
\end{array}$ & $\begin{array}{c}182 \\
(429) \\
\end{array}$ & 3.9 & $8 \cdot 0$ \\
\hline Suicide (282) & 23 & 29 & 37 & 26 & 33 & 57 & 25 & 34 & $2 \cdot 8$ & $4 \cdot 2$ \\
\hline Poisoning (114) & 7 & 9 & 19 & 15 & 16 & 31 & 10 & 12 & $3 \cdot 4$ & $3 \cdot 8$ \\
\hline Traffic accidents (135) & 17 & 12 & 16 & 21 & 7 & 22 & 18 & 12 & $-0 \cdot 7$ & 0.4 \\
\hline Falls (99) & 8 & 12 & 13 & 17 & 10 & 11 & 7 & 12 & 1.5 & 0.6 \\
\hline Other trauma (194) & 17 & 22 & 28 & 23 & 23 & 46 & 20 & 18 & 1.3 & 2.9 \\
\hline $\begin{array}{l}\text { All trauma and poisoning } \\
\text { (No of deaths 824) }\end{array}$ & $\begin{array}{r}72 \\
(114) \\
\end{array}$ & $\begin{array}{c}84 \\
(165) \\
\end{array}$ & $\begin{array}{c}114 \\
(254) \\
\end{array}$ & $\begin{array}{l}103 \\
(81)\end{array}$ & $\begin{array}{c}90 \\
(80) \\
\end{array}$ & $\begin{array}{l}172 \\
(93) \\
\end{array}$ & $\begin{array}{c}79 \\
(95) \\
\end{array}$ & $\begin{array}{c}88 \\
(196) \\
\end{array}$ & 3.8 & 5.5 \\
\hline $\begin{array}{l}\text { Unknown cause } \\
\text { (No of deaths 217) }\end{array}$ & $\begin{array}{c}17 \\
(27)\end{array}$ & $\begin{array}{c}29 \\
(78)\end{array}$ & $\begin{array}{c}34 \\
(38) \\
\end{array}$ & $\begin{array}{c}33 \\
(13) \\
\end{array}$ & $\begin{array}{c}30 \\
(13) \\
\end{array}$ & $\begin{array}{c}41 \\
(12)\end{array}$ & $\begin{array}{c}16 \\
(29) \\
\end{array}$ & $\begin{array}{c}24 \\
(45) \\
\end{array}$ & $2 \cdot 3$ & $2 \cdot 8$ \\
\hline $\begin{array}{l}\text { All causes } \\
\quad \text { (No of deaths 20 523) }\end{array}$ & $\begin{array}{c}1706 \\
(2215)\end{array}$ & $\begin{array}{c}2113 \\
(4802)\end{array}$ & $\begin{array}{l}3038 \\
(5280)\end{array}$ & $\begin{array}{c}2542 \\
(1767)\end{array}$ & $\begin{array}{c}3004 \\
(1895)\end{array}$ & $\begin{array}{l}3928 \\
(1618)\end{array}$ & $\begin{array}{l}2078 \\
(3187)\end{array}$ & $\begin{array}{l}2130 \\
(5039)\end{array}$ & 18.9 & $27 \cdot 7$ \\
\hline
\end{tabular}

If smoking is unrelated to mortality from a particular disease the standardised trend test has expectation zero and a standard deviation of unity, so values above $1.96,2 \cdot 57$, and 3.29 correspond to $P$ values (two tailed) of $0.05,0.01$, and 0.001 .

$+\mathrm{N} / \mathrm{X} / \mathrm{S}=$ non-smokers, former smokers of any type of tobacco, current smokers of any type.

$\ddagger 0 / 1-14 / 15-24 / \geqslant 25=$ non-smokers, smokers of $1-14,15-24$, and 25 or more cigarettes only.

TABLE VI-Total mortality by smoking habits and age at death

\begin{tabular}{|c|c|c|c|c|c|c|}
\hline \multirow[b]{4}{*}{ Age at death (years) } & \multicolumn{6}{|c|}{ Annual mortality per 1000 men $^{\star}$} \\
\hline & \multirow{3}{*}{$\begin{array}{c}\text { Non-smokers } \\
\text { (never smoked } \\
\text { regularly) }\end{array}$} & \multicolumn{3}{|c|}{ Cigarette smokers only } & \multicolumn{2}{|c|}{ Other smokers } \\
\hline & & \multirow[b]{2}{*}{ Former } & \multicolumn{2}{|c|}{ Current } & \multirow[b]{2}{*}{ Former } & \multirow[b]{2}{*}{ Current } \\
\hline & & & All & $\geqslant 25 /$ day & & \\
\hline $35-44$ & $(1 \cdot 6) \dagger$ & $(2 \cdot 0)$ & $2 \cdot 8$ & $(5 \cdot 1)$ & $(2 \cdot 8)$ & $(1 \cdot 6)$ \\
\hline $45-54$ & 4.0 & $4.9)$ & $8 \cdot 1$ & 10.8 & $(4 \cdot 8)$ & $5 \cdot 5$ \\
\hline $55-64$ & 9.5 & $13 \cdot 4$ & $20 \cdot 3$ & $26 \cdot 0$ & 11.2 & 12.5 \\
\hline $65-74$ & $23 \cdot 7$ & $31 \cdot 6$ & $47 \cdot 0$ & $60 \cdot 7$ & $30 \cdot 5$ & $32 \cdot 4$ \\
\hline $75-84$ & $67 \cdot 4$ & $77 \cdot 3$ & $106 \cdot 4$ & $117 \cdot 0$ & $77 \cdot 6$ & $79 \cdot 4$ \\
\hline$\geqslant 85$ & $168 \cdot 6$ & $179 \cdot 7$ & $218 \cdot 7$ & $(284 \cdot 7)$ & $186 \cdot 1$ & $179 \cdot 8$ \\
\hline \multicolumn{7}{|c|}{ All ages, including under } \\
\hline 35 years & $17 \cdot 1$ & $21 \cdot 1$ & $30 \cdot 4$ & $39 \cdot 3$ & $20 \cdot 8$ & $21 \cdot 3$ \\
\hline (No of deaths) & (2115) & $(4802)$ & $(5280)$ & (1618) & (3187) & (5039) \\
\hline
\end{tabular}

* Standardised for age in five year age groups up to age $\geqslant 95$

+ Parentheses indicate rates based on fewer than 100 deaths. The coefficient of variation of each rate is approximately equal to the inverse of the square root of the number of deaths on which that rate is based; hence, rates based on fewer equal to the inverse of the square root of the number of deaths on which 100 deaths have a coefficient of variation that exceeds $0 \cdot 1(10 \%)$.
than

diseases," suicide, and poisoning. Hernia, which we had classed previously as closely related to smoking, ${ }^{6}$ is included in "other digestive diseases" as only 25 deaths were attributed to it. The mortality from hernia was higher in current smokers than in non-smokers and in heavy than in light cigarette smokers, but the trends were not statistically significant and the relation was less close in the second than in the first half $f^{5}$ of the study. Deaths attributed to "other violence" (but not deaths from traffic accidents or falls) were also related to smoking, but less clearly so than deaths from suicide and poisoning.

One disease showed a statistically significant negative relation with smoking: namely, parkinsonism. Mortality from this condition was higher in former smokers than in continuing smokers, presumably because the effects of the disease made smoking difficult, but it was almost the same in former smokers and non-smokers, so that the annual mortality in ever smokers (16 per 100000) was lower than in lifelong non-smokers (20 per 100000), supporting earlier evidence that smoking inhibits the development (or the progress) of the disease. ${ }^{20}$ No useful information was obtained to test the hypotheses that two other diseases might be negatively related to smoking-ulcerative colitis $^{21}$ and, more speculatively, Alzheimer's disease ${ }^{22}$ -as only eight deaths were attributed to ulcerative colitis and 19 to Alzheimer's disease. It may be noted, however, that the annual mortality from dementia (regarded as including all deaths classified under ICD 7th revision Nos 304-306 and 9th revision Nos 290 and 331), about half of which is probably attributable to Alzheimer's disease, was similar in non-smokers (nine per 100000$)$ and ever smokers (11 per 100000 ).

\section{MORTALITY BY SMOKING HABIT, BY AGE}

No death was observed in men under 25 years of age and the total number observed at 25-34 years of age was so small (67) that mortality rates in different smoking categories were subject to large random variation. We can, therefore, usefully compare age specific mortality in detailed smoking categories only from about 35 years of age upwards, although it may be noted that under 35 years of age the mortality was higher in current smokers ( 1.5 per 100000 per year, based on 35 deaths) than in non-smokers (1.1 per 100000 per year, based on 17 deaths). No new members were recruited to the study after 1951 , so the mortality at $35-44$ years of age was observed almost entirely in the first two decades (November 1951 to October 1971) and mortality during the fourth decade of the study (November 1981 to October 1991) will have contributed materially only to ages 55 and over.

The data in table VI show that, for the 40 year period of the study as a whole, the overall mortality was twice as great in continuing cigarette smokers as in lifelong non-smokers throughout middle and early old age. The proportional excess in cigarette smokers decreased, however, in later life, and the ratio was reduced to $1 \cdot 6: 1$ at $75-84$ years of age and $1 \cdot 3: 1$ at ages 85 years and over. Some of the decrease can be attributed to a reduction with age in the average amounts smoked by continuing smokers (shown in table II), some to the reduction in the proportion of deaths from cancer (from $24 \%$ of all deaths at ages $65-74$ years to $11 \%$ at ages 85 years and over), and some to the progressive reduction in the ratio of the mortality in cigarette smokers to that in non-smokers that is seen for deaths from cardiovascular disease (from $2 \cdot 1$ at ages 
under 65 through 1.7 and 1.4 , to 1.2 at ages 85 years and over). How the ratios change with age for the diseases most closely related to smoking is unclear, as the numbers of deaths in non-smokers in each age group are too small to provide stable estimates.

\section{ACTUARIAL SURVIVAL BY SMOKING HABIT}

As the observations have been made over such a long time, it has been possible to follow many men into their 10 th - and a few even into their 11 th-decade of life. It has, therefore, been possible to calculate "actuarial" survival curves for different categories of smoker not only throughout middle age but also into old age, with results that are reasonably reliable up to at least 85 years of age. The results from 35 years of age are shown for non-smokers and continuing cigarette smokers in figure 1, and for non-smokers and continuing light, moderate, and heavy cigarette smokers in figure 2 . The most notable differences are in the proportions who die between 35 and 69 years of age, which vary from $20 \%$ in non-smokers to $41 \%$ in cigarette smokers as a whole and to $50 \%$ in those who smoke 25 or more cigarettes a day. The absolute differences between the survival probabilities of smokers and of non-smokers become less in extreme old age, simply because almost nobody survives beyond 100 . Even after middle age, however, the differences between smokers and non-smokers in their annual mortality rates are quite large: of those alive at 70 , the probability of surviving to 85 is $41 \%$ in non-smokers against $21 \%$ in cigarette smokers. The loss of expectation of life shown by these figures is substantial. For cigarette smokers, the age by which half have died is eight years less than for non-smokers,

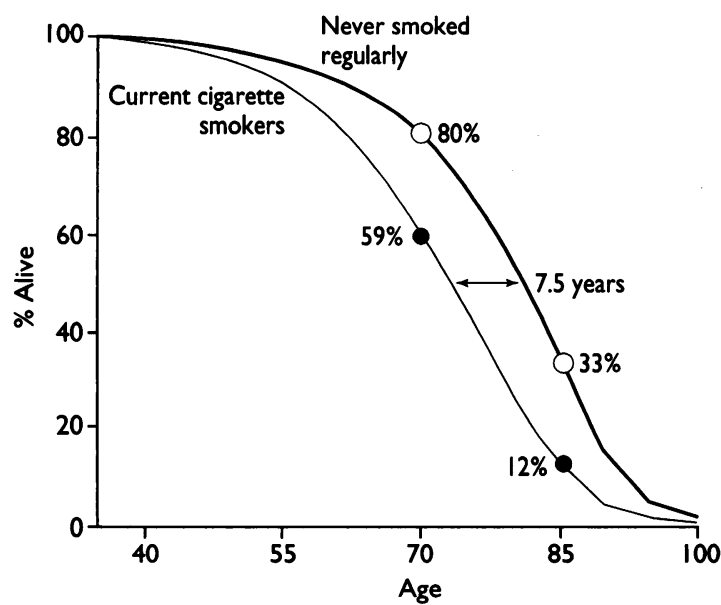

FIG 1-Overall survival after age 35 among cigarette smokers and nonsmokers: life table estimates, based on age specific death rates for the entire 40 year period. (Note that, at 1990 British death rates, $97 \%$ of male infants would survive from birth to 35 years of age)

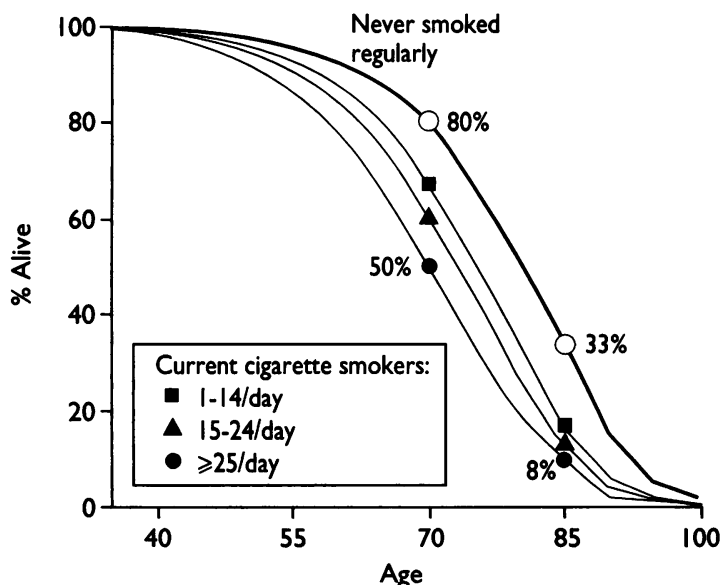

FIG 2-Overall survival (as fig 1), but with cigarette smokers subdivided by amount they were smoking at the time their last questionnaire was returned

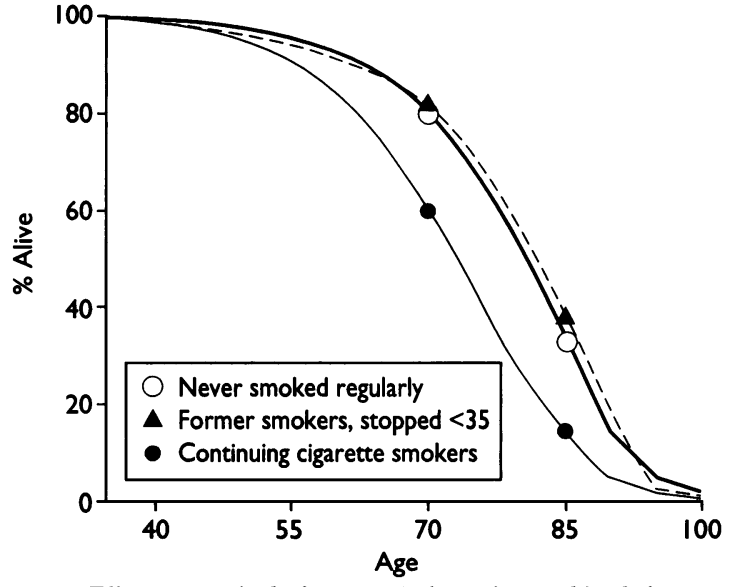

FIG 3-Effects on survival after age 35 of stopping smoking before age 35: life table estimates (as fig 1)

while for heavy cigarette smokers it is 10 years less than for non-smokers.

Assessment of the effects of stopping smoking is complicated by the fact that people stop for different reasons, some stopping (particularly in old age or late middle age) because they are ill; conversely, some may, because they are ill, specifically choose not to stop, thinking that it is too late for any benefit from so doing. ${ }^{\circ}$ Most of those who stopped in the doctors' cohort are likely to have done so not because of an established illness but to avoid long term effects of smoking or to set an example, ${ }^{23}$ and their state of health at the time they stopped (particularly if they stopped in early middle age or before) should not have distorted materially the pattern of their long term survival. The pattern will, however, be substantially distorted for a few causes of death that are preceded by long term irreversible morbidity, most notably, chronic obstructive lung disease. ${ }^{64}$

The survival of cigarette smokers who stopped at different ages is compared in figures 3 and 4 with that of non-smokers and with that of those who continued to smoke. Those who stopped before 35 years of age (at a mean of 29 years) had a pattern of survival that did not differ significantly from that of non-smokers (fig 3 ; two tailed $P>0 \cdot 05$ ). For those who stopped later (fig 4) the survival was intermediate between that of nonsmokers and that of continuing smokers; but even those who stopped at 65-74 years of age (mean 71 years) had age specific mortality rates beyond age 75 years appreciably lower than those who continued. The benefit of stopping in late middle age or old age is probably underestimated in these analyses because some of those who stopped in later life are likely to have done so specifically because of being ill.

\section{CHANGE IN MORTALITY AND SURVIVAL OVER TIME}

In the course of 40 years many changes have occurred that could have modified the effect of smoking, including the efficacy of medical treatments (both therapeutic and preventive), the prevalence of other factors that interact with smoking, the type of tobacco smoked, and the amount of tobacco that had been smoked in the even more distant past. We have therefore calculated the excess risk (cigarette smokers versus non-smokers) separately during the first half (1951-71) and the second half (1971-91) of the study. These excesses are shown for five age groups in figure 5. No figure is given for men under 45 years of age in the second half of the study as the number of men in this age group in 1971 was too small to permit a reliable comparison. As a percentage of the mortality among those who had never smoked regularly, the excess among current cigarette smokers was consistently higher in the second half than in the first, particularly 

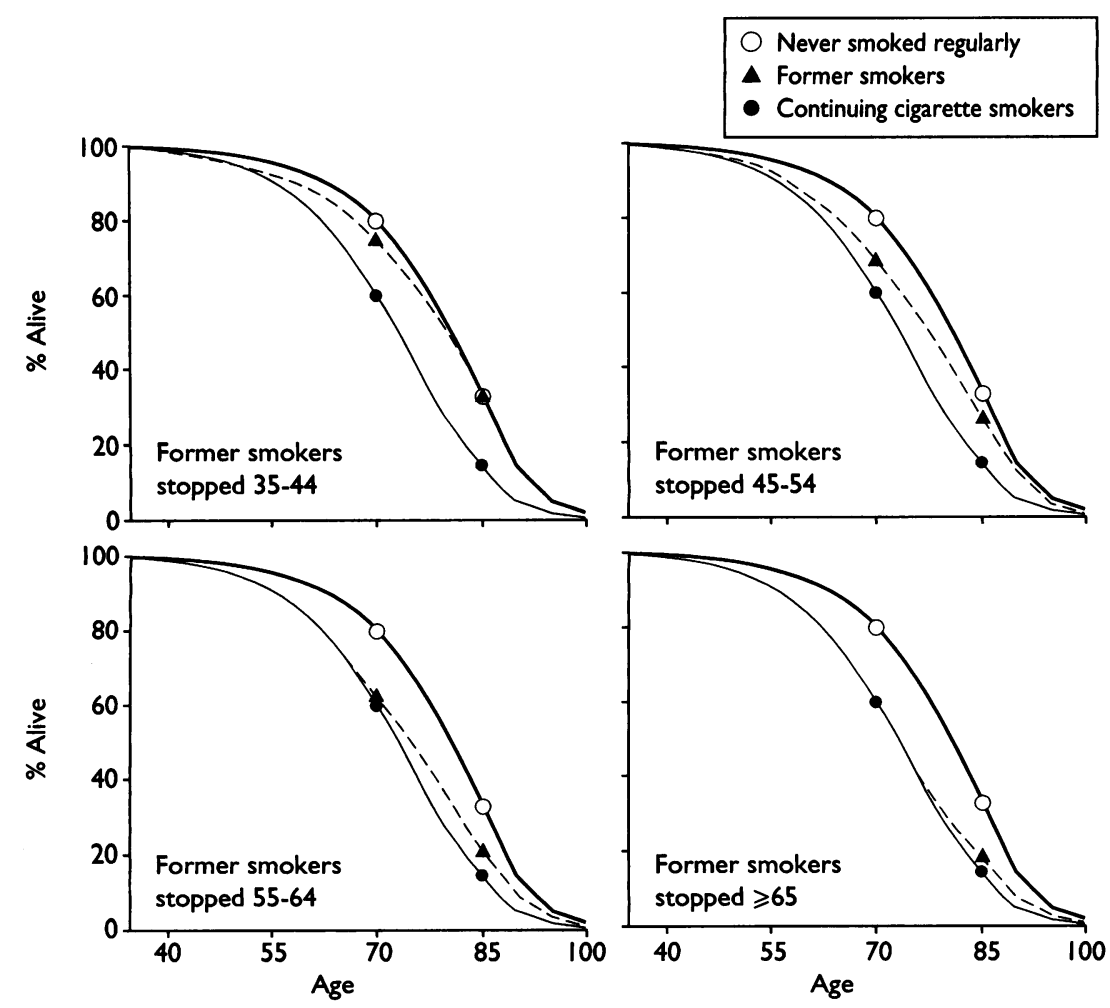

FIG 4-Effects on survival after ages 45, 55, 65, and 75 of stopping smoking in previous decade: life table estimates (as in fig 1)

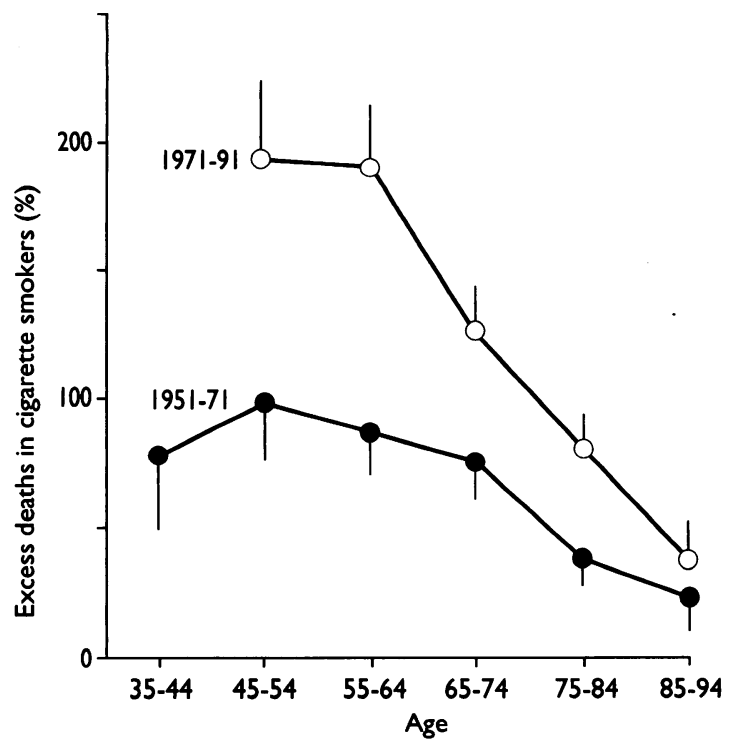

FIG 5-Excess age specific mortality in cigarette smokers in first half of study (lower line) contrasted with that in only second half (upper line). An excess of $100 \%$ represents doubled death rate. Bars indicate SD
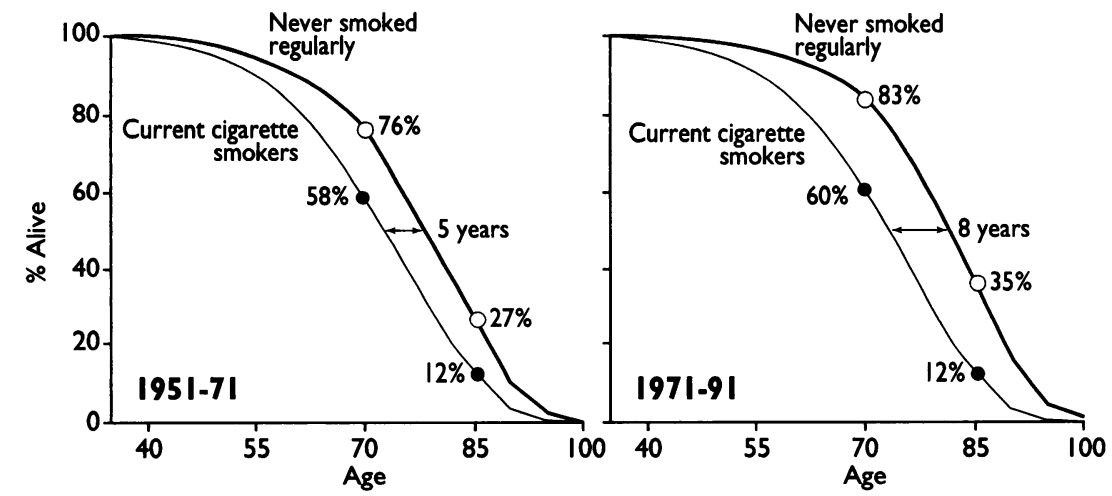

FIG 6-Survival after age 35 among cigarette smokers and non-smokers in first half (left) and second half of study (right). For ages 35-44 rates for the whole study are used in both halves since little information on these is available from the second half in late middle age. Examination of the separate survival curves for non-smokers and for cigarette smokers shows that the increase in relative risk was so extreme that it counterbalanced the substantial improvement that has taken place over the past few decades in the survival of the non-smokers (fig 6). Overall, therefore, there was practically no change between the first and second halves of the study in the age specific patterns of survival of the cigarette smokers (fig 6), even though this was a period when national mortality rates were improving rapidly.

Changes in mortality between the two halves of the study are shown in table VII for some of the principal causes of death in non-smokers and in continuing cigarette smokers. (The detailed age specific rates are given in the appendix.) To allow for $2.0 \%$ of the causes of death in the second half of the study being unknown while only $0.05 \%$ were unknown in the first half, and for the possibility that some 50 deaths in the 40th year were missed, the cause specific mortality rates in the whole of the second half have been multiplied by $1 \cdot 025$. As few doctors were under 45 years of age in the second period, the rates are limited to men aged 45 years and over and are standardised to a population with the age distribution of the person years at risk over 45 years for the whole period. Most of these standardised rates, in consequence, are higher than those recorded in tables III-V.

Mortality in non-smokers for the most part decreased: from cerebrovascular diseases by $31 \%$, from ischaemic and other cardiovascular diseases by $30 \%$, and from respiratory disease other than chronic obstructive lung disease by $32 \%$. The large reduction in mortality attributed to "other cardiovascular disease" is probably a nosological artefact due to the greater use of ischaemic heart disease as a diagnostic term in the second half of the study in place of vaguer terms like myocardial degeneration and arteriosclerosis. The true reduction in mortality from ischaemic heart disease is therefore likely to have been greater than the recorded figure. The proportions of the reduction that should be attributed respectively to the introduction of preventive measures and improved treatment are not known but both must be appreciable. The reduction of $30 \%$ in mortality from the cancers other than lung cancer that are caused in part by smoking could be chiefly due to random variation, since the numbers of deaths in non-smokers were small (18 and 25) but it could also reflect a reduction in the prevalence of carcinogenic agents other than tobacco, as most of the deaths in this category were from cancers of the pancreas and bladder, both of which have other important causes. The mortality in non-smokers from lung cancer, in contrast, seems to have remained constant, although the numbers are small. (The much larger prospective studies in the United States have also found no material change in mortality due to lung cancer in non-smokers between the 1960s and the 1980s. ${ }^{11}$ )

In smokers, the reductions in cause specific mortality, when they occurred, were smaller than in non-smokers (cerebrovascular disease was approximately constant, while ischaemic and other cardiovascular disease, taken together, decreased by only about a quarter). In several instances, reductions in non-smokers were accompanied by increases in smokers, most notably in the mortality from the cancers other than lung cancer that are caused by smoking, from respiratory disease other than chronic obstructive lung disease, and from "other diseases"; lung cancer, which was unchanged in non-smokers, increased in smokers by $19 \%$.

Two conditions showed increased mortality in both non-smokers and smokers. For chronic obstructive lung disease the rates in non-smokers were based 
Annual death rate per 100000 men

\begin{tabular}{|c|c|c|c|c|}
\hline \multirow[b]{3}{*}{ Cause of death } & \\
\hline & \multicolumn{2}{|c|}{ Never smoked regularly } & \multicolumn{2}{|c|}{ Current cigarette smokers } \\
\hline & $1951-71$ & $1971-91$ & $1951-71$ & $1971-91$ \\
\hline All neoplastic causes & 382 & 394 & 743 & 993 \\
\hline Lung cancer & 17 & 17 & 264 & 314 \\
\hline Other cancers substantially affected by smoking ${ }^{\star}$ & 75 & 55 & 150 & 261 \\
\hline Other neoplastict & 290 & 322 & 329 & 418 \\
\hline All respiratory causes & 163 & 121 & 384 & 466 \\
\hline Chronic obstructive lung disease & 7 & 15 & 151 & 208 \\
\hline Other respiratory disease & 156 & 106 & 233 & 258 \\
\hline All vascular causes & 1626 & 1153 & 2416 & 2003 \\
\hline Cerebrovascular disease & $\begin{array}{r}401 \\
1225\end{array}$ & $\begin{array}{l}278 \\
857\end{array}$ & $\begin{array}{r}516 \\
1900\end{array}$ & $\begin{array}{r}501 \\
1502\end{array}$ \\
\hline Other diseases & 258 & 198 & 370 & 388 \\
\hline Trauma and poisoning & 94 & 74 & 119 & 156 \\
\hline All causes & 2523 & 1954 & 4077 & 4026 \\
\hline
\end{tabular}

*Includes cancer of unknown site, plus remaining types recognised by the International Agency for Research on Cancer ${ }^{12}$ as being able to be caused by smoking.

†For some of these sites (for example, stomach or liver) a small proportion of cases may be caused by smoking, and this category may include some misdiagnosed cancers of sites substantially affected by tobacco.

on such small numbers (two in the first half and 10 in the second) that the increase may well have been due to chance. For the aggregate of all types of cancer that are "not associated" with smoking the increase in nonsmokers was small (11\%) but in smokers it was spread across a wide range of cancers and was somewhat larger $(27 \%)$.

\section{Discussion}

CAUSATION, CONFOUNDING, AND CHANCE

In general, the results in this study for specific causes of death accord with those in many other studies. Reinforced by other evidence, they helped lead more than 30 years $\operatorname{ago}^{7925}$ to the conclusion that the associations observed between smoking habit and mortality are chiefly causal in character (see also the more recent reviews by the US Surgeon General ${ }^{11}$ and the International Agency for Research on Cancer. ${ }^{12}$ ) In most of the causal associations, smoking seems to act synergistically with other aetiological agents such as consumption of alcohol ${ }^{126}$; various aspects of $\operatorname{diet}^{27}$; level of blood pressure, blood lipids, or other cardiovascular risk factors ${ }^{28}$; or exposure to asbestos, ${ }^{12}$ radon, ${ }^{29}$ or possibly some infective factors. ${ }^{30}$ The quantitative effect of smoking will, therefore, vary with variation in the prevalence of these other agents.

In some instances smoking and other aetiological agents may also be confounded, as with the consumption of alcohol, ${ }^{31}$ various aspects of personality, ${ }^{32}{ }^{33}$ and perhaps some aspects of diet. ${ }^{34}{ }^{35}$ Indeed, for a few causes of death the confounding between smoking and other factors may account for virtually all the observed association with smoking, in which case none of the excess mortality from those causes should be attributed to the habit. The only plausible examples of important associations that might be due to this, however, are those that involve cirrhosis, suicide, and other traumatic causes, for which the associations with smoking may be secondary to associations with alcohol and personality.

The close association between smoking and drinking habits was confirmed when, in 1978, the doctors in this study were invited to volunteer for a controlled trial of the value of aspirin as a prophylactic against the development of vascular disease in previously healthy men, ${ }^{17}$ for the 1978 questionnaire also inquired about the consumption of alcoholic drinks. Among 12322 doctors who replied, the proportion who drank 42 units or more per week (a half pint of beer, a glass of wine, or a single measure of spirits each constituting one unit) increased progressively from $2 \%$ in those who had never smoked regularly to $20 \%$ in men then smoking 25 or more cigarettes a day. If, therefore, death from cirrhosis was chiefly limited to men consuming 42 or more units per week, it would not be difficult to explain, as the result of confounding with the consumption of alcohol, most or all of the substantial excess of deaths from cirrhosis that is observed when heavy cigarette smokers are compared with non-smokers. Nor would it be difficult to explain at least a part of the excess mortality from suicide and poisoning in cigarette smokers in the same way, if these conditions were also associated with the consumption of alcohol (albeit less closely than is the case for cirrhosis of the liver).

The attribution of some of the excess mortality in cigarette smokers to confounding does not, however, necessarily mean that the overall effect of smoking on all cause mortality is less than that observed, as the factors with which tobacco is confounded may also have other effects which tend to reduce mortality. This is probably the case with alcohol, the consumption of which (at least in moderation) is associated with a reduced risk of ischaemic heart disease. ${ }^{36}{ }^{37}$ If, as now seems likely, the consumption of a few units of alcohol a day can reduce the age specific mortality from ischaemic heart disease, then the confounding of cigarette consumption with the consumption of alcohol would mean that the total effect of cigarette smoking on ischaemic heart disease mortality is slightly more than that hitherto reported. The analysis of our own date on the effects of alcohol consumption is complex, because the doctors recorded as non-drinkers include some who gave up on health grounds; this is reported in detail elsewhere. ${ }^{37}$ It may be noted, however, that preliminary estimates of the ratio of the mortality from ischaemic heart disease in cigarette smokers to that in non-smokers in the population with both smoking and drinking habits is $1 \cdot 58: 1$ without standardisation for the consumption of alcohol and 1·76:1 after standardisation.

Whether the same is true of the confounding with personality, which could contribute to the excess mortality in cigarette smokers from suicide and poisoning, is another matter. It would seem unlikely, and in the absence of evidence to the contrary the contribution of these conditions to the excess mortality in cigarette smokers should perhaps be omitted, along with that of all other causes of violent death, when the contribution of smoking to the likelihood of premature death is estimated. Likewise, no deaths from these causes were attributed to smoking when estimates were being made of the worldwide mortality that is attributable to the habit in developed countries. ${ }^{38}$

There remain a few causes of death which, in our study, are related to smoking for reasons that are unclear. One is cancer of the rectum (table III) which was significantly related to smoking in our previous report ${ }^{6}$ and continues to show much the same relation in these data with twice as many deaths. Colorectal cancer has not generally been related to smoking in other studies, though it has been in some..$^{39}$ Colorectal adenomas, however, have consistently been related to smoking and it has been suggested, on the basis of an American cohort study, ${ }^{40}$ that cigarette smoke acts as an initiating agent and that a relation with cancer will be observed only after an induction period of several decades. (In that study a relation was recorded for small adenomas with smoking habits over the previous 20 years, and for larger adenomas with smoking habits more than 20 years previously.) If our data for colon and rectal cancer are combined, the association with smoking is still significant, but no longer particularly close, and a possible explanation of our results is that they reflect a real but weak association between colorectal cancer and smoking that has been inflated by the play of chance, particularly for rectal cancer. Whether such an association is causal ${ }^{40}$ or reflects 
confounding with alcohol or with $\operatorname{diet}^{264142}$ remains to be seen.

The association (table V) with peptic ulcer is likely to be largely or wholly causal, that with cirrhosis is likely to be largely or wholly non-causal, and the associations with the heterogeneous group of other diseases in table $\mathrm{V}$ may reflect some causal effects on diseases that are not responsible for many deaths and whose relation with smoking has not been commonly studied, some confounding, some misdiagnosis, and some chance fluctuations.

Lastly, there was a weak relation with smoking for deaths from "other violence," after suicide, poisoning, traffic accidents, and falls were excluded. Some of these deaths-attributed, for example, to gunshot wounds-could have been unrecognised cases of suicide and due to confounding with alcohol and personality. At least two deaths were, however, directly attributable to smoking: namely, those due to conflagration from smoking in bed.

\section{TEMPORAL TREND IN EXCESS MORTALITY IN SMOKERS}

A completely new feature of our results is the greater absolute and (particularly in middle age) relative excess of mortality associated with smoking in the second half of the study compared with the first. When current cigarette smokers were compared with lifelong nonsmokers, the excess mortality associated with smoking was already substantial during 1951-71, but it was considerably more extreme during 1971-91. During 1951-71, the death rates in cigarette smokers were about double those in non-smokers throughout middle age; during 1971-91, the corresponding difference was nearly treble. If, as is likely, most of the difference in mortality between smokers and non-smokers is actually caused by smoking then a threefold excess would imply that about two thirds of the deaths in middle age among the smokers were caused by tobacco. Even at older ages the excess mortality associated with tobacco was substantially greater in 1971-91 than it was during 1951-71. This difference between the apparent effects of tobacco in the two periods arose because age specific mortality decreased substantially only among non-smokers.

It may seem that if there is a difference of five years in median survival between smokers and non-smokers during 1951-71 and a difference of eight years during 1971-91 (both shown in fig 6) then a difference of about $61 / 2$ years (the average of 5 and 8 years) might have been expected in the overall results, but in fact there was a difference of $7 \frac{1}{2}$ years (fig 1 ). This is because most of the deaths in non-smokers occurred in the second half of the study. So mortality in non-smokers for 1951-91 in figure 1 is closer to that in 1971-91 than to that in 1951-71, whereas the mortality in smokers was approximately constant in both halves of the study.

An improvement in the survival of non-smokers was to be expected, as there have been many major advances in preventive and therapeutic medicine. Diet has improved in several ways. The treatment of hypertension and ischaemic heart disease has improved (and national mortality from vascular diseases has been decreasing rapidly), the urban environment has become less heavily polluted with coal smoke, and the impact of AIDS has had little effect on men of the generations studied. In the United States, a comparison by the Surgeon General of two prospective surveys of a million people, one in the 1960 s and one in the 1980 s, found no evidence of a change in lung cancer rates in non-smokers over a 20 year period but a big decrease in the mortality from coronary heart disease. ${ }^{.1}$ Likewise, in the present much smaller study there has, over the same period, been no evidence of any change in the mortality of non-smokers from lung cancer, although there has been a substantial reduction in their

\section{Clinical implications}

- Observations on the mortality of British doctors with known smoking habits have been reported over a 20 year period (1951-71); now the study period has been extended to 40 years (1951-91) and covers over 20000 deaths

- Overall, the excess mortality of cigarette smokers was approximately twice as extreme in the second half as in the first half of this study

- Twenty five causes of death were significantly associated with cigarette smoking (24 positively and one negatively)

- Even in middle age stopping smoking substantially increased the subsequent expectation of life-and those who stopped before 35 years of age had an expectation of life that was not significantly different from that of non-smokers

mortality attributed to stroke and also to heart disease (if we combine ischaemic heart disease and other cardiovascular disease, as probably needs to be done to take account of nosological changes).

It is easy enough to understand why the mortality in non-smokers should have improved, but why has it not done so in cigarette smokers, who have generally experienced the same benefits of prevention and therapeutic medicine and have had the added advantage of the switch to cigarettes delivering low tar? The change in the type of cigarette would have had only a moderate effect on the overall hazards of smoking, for although it should have reduced the hazard of lung cancer ${ }^{1213}$ it may well have had little effect on mortality from the other main diseases caused by tobacco, particularly those that depend on deep inhalation, such as chronic obstructive lung disease ${ }^{6}$ and ischaemic heart disease. ${ }^{43}$

What seems to have been more important ${ }^{1538}$ is the "maturing" of the epidemic of deaths of British men from smoking with those who reached later middle or old age in the 1970s and 1980s having had a longer history of regular consumption of cigarettes than men of the same ages would have had during the 1950s and 1960s. Another factor that may be important in the maturing of the epidemic (but which is impossible to quantify) is a change in the way cigarettes have been smoked in recent decades. The minority of doctors who continued to smoke cigarettes in the latter half of the study may have tended to be those who smoked them in a different way from that of the greater number who had stopped smoking them earlier. The finding of a relatively increased risk from cigarette smoking in the second half of the study is not unique, for it parallels the findings in the two massive cohort studies carried out by the American Cancer Society, one in the 1960s and one in the $1980 \mathrm{~s}$, which show a similar increase over time in the excess mortality in cigarette smokers. ${ }^{11}$

If quantitative estimates of the current hazards of tobacco in developed countries are to be made, ${ }^{3844}$ they should be based on fairly recent epidemiological evidence, such as the second half of the present study or, better (because it involves much larger numbers), the second million person prospective study in the United States. ${ }^{11384}$ But, whatever its size, no single epidemiological study can provide an adequate basis for assessing the worldwide epidemic of death from tobacco, because the epidemic is at a different stage, and is evolving so differently, in different populations. In almost all developed countries lung cancer rates in women are now rising (which impedes prediction of the eventual hazard for women); in some the rates in men are still rising, in others they are falling, and in less developed countries where there has only in 
recent decades been a large increase in cigarette use among men, large increases in mortality from tobacco in men must be expected in the early decades of the next century as the future health effects of current smoking patterns..$^{44}$ The substantial differences between the effects of tobcco during the first and second halves of the present study underline the need for a worldwide network of prospective studies that can monitor the increases, and eventual decreases, in this great epidemic throughout the world.

The Imperial Cancer Research Fund and, previously, the Medical Research Council have supported this study for several decades. The British Medical Association, the Office of Population Censuses and Surveys, the General Register Office for Scotland, and the General Medical Council have consistently provided assistance, and we have had help from the General Register Office for Northern Ireland; corresponding offices in the Isle of Man, Jersey, Guernsey, and Alderney; the Department of Social Security; the Office of the Paymaster General; and many family health services authorities in England and Wales and area health boards in Scotland. We are grateful to them for their assistance and to the many individuals who have helped either scientifically or in tracing doctors and maintaining records, particularly: $\mathrm{B}$ Armstrong, G Bourke, A Clarke, R Collins, J Gilliland, N Gray, B Hafner, J Halliwell, R Harris, C Hennekens, $M$ Hughes, $K$ Jamrozik, K Jones, J Kaldor, J Kench, R MacLennan, J Mathews, Milner, B Norman-Smith, S Norton, J Olsen, M Pike, A Radley, R Ripley, F Sitas, D Skegg, F Speizer, E Thompson and $M$ Vessey. The chief acknowledgment, however, is to the many doctors who have replied to our questionnaires. The manuscript was typed by C Harwood. This 40 year report is dedicated to the achievements of Charles Fletcher ${ }^{7}$ and the memory of its initiator, Sir Austin Bradford Hill (1897-1991).

1 Doll R, Hill AB. Smoking and carcinoma of the lung. Preliminary report BMF 1950;ii:739-48.

2 Wynder EL, Graham EA. Tobacco smoking as a possible etiologic factor in bronchogenic carcinoma. $¥ A M A$ 1950;143:329-36.

3 Doll $\mathrm{R}$, Hill $\mathrm{AB}$. The mortality of doctors in relation to their smoking habits. A preliminary report. $B M 7$ 1954;i: $1451-5$.
4 Doll $R$, Hill $A B$. Lung cancer and other causes of death in relation to smoking. A second report on the mortality of British doctors. BMF 1956;ii:1071-6.

5 Doll R, Hill AB. Mortality in relation to smoking: ten years' observations of British doctors. BMF 1964;i:1399-414, 1460-7.

6 Doll R, Peto R. Mortality in relation to smoking: 20 years' observations on male British doctors. $B M \mathcal{F} 1976$;ii: $1525-36$

7 Royal College of Physicians. Smoking and health. London: Pitman Medical Publishing, 1962.

8 Royal College of Physicians. Smoking and health now. London: Pitman Medical and Scientific Publishing, 1971.

9 Surgeon General. Smoking and health. Report of the Advisory Committee to the Surgeon General of the Public Health Service. Washington, DC: US Government Printing Office, 1964

10 Surgeon General. Smoking and health. Washington, DC: US Government Printing Office, 1979.

11 Surgeon General. Reducing the health consequences of smoking: 25 years of progress. Report of the Surgeon General, 1989. Rockville, MD: US Department of Health and Human Services, 1989.

12 International Agency for Research on Cancer. (IARC monographs on the evaluation of the carcinogenic risk of chemicals to humans Lyons, IARC 1986 (No 38.)

13 Zaridze D, Peto R, eds. Tobacco: a major international health hazard. Lyons: International Agency for Research on Cancer, 1986. (IARC scientific publication No 74 .

14 Doll R, Gray R, Hafner B, Peto R. Mortality in relation to smoking: 22 years observation on female British doctors. BMf 1980;280:967-71.

15 Doll R, Peto $R$. The causes of cancer: quantitative estimates of avoidable risks of cancer in the United States today. 7 Natl Cancer Inst 1981;66:1191-308.

16 Peto R. Influence of dose and duration of smoking on lung cancer rates. In: Zaridze D, Peto R, eds. Tobacco: a major international health hazard. Lyons: Zaridze D, Peto R, eds. Tobacco: a major international health hazard. Lyons: publication No 74.)

17 Peto R, Gray R, Collins R, Wheatley K, Hennekens C, Jamrozik K, et al. Randomised trial of prophylactic daily aspirin in British male doctors. $B M \mathcal{f}$ 1988;296:313-6.

18 World Health Organisation. Manual of the international statistical classification of diseases, injuries and causes of death. Seventh revision. Geneva: WHO, 1957.

19 World Health Organisation. Manual of the international statistical classification of diseases, injuries, and causes of death. Ninth revision, 1975. Geneva: WHO, 1977

20 Marmot M. Smoking and Parkinson's disease. In: Wald N, Baron J, eds. Smoking and hormone related disorders. Oxford: Oxford University Press, 1990:135-41.

21 Logan RFA. Smoking and inflammatory bowel disease. In: Wald N, Baron J, eds. Smoking and hormone related disorders. Oxford: Oxford University Press, 1990:122-34.

22 Graves AB, Van Duijn CM, Chandra V, Fratiglioni L, Heyman A, Jorm AF, et al. Alcohol and tobacco consumption as risk factors for Alzheimer's disease: a collaborative reanalysis of case-control studies. Int $f$ Epidemiol 1991;20(suppl 2):S48-57.

23 Fletcher C, Doll R. A survey of doctors' attitudes to smoking. Br $f$ Prev Soc Med 1969;23:145-53.

24 Fletcher CM, Peto R. The natural history of chronic airflow obstruction. Br Heart f 1977;1:1645-8.

APPENDIX-Cigarette $v$ never smokers: annual mortality per 100000 men in first half (1 November 1951 to 31 October 1971) and second half (1 November 1971 to 31 October 1991 ) of prospective study of British doctors

\begin{tabular}{|c|c|c|c|c|c|c|c|c|c|c|c|c|c|c|c|c|c|c|c|c|c|c|}
\hline \multirow{2}{*}{$\begin{array}{l}\text { Age at death } \\
\text { and smoking } \\
\text { habits when } \\
\text { last asked }{ }^{\star}\end{array}$} & \multicolumn{2}{|c|}{ Lung cancer } & \multicolumn{2}{|c|}{$\begin{array}{l}\text { Cancer of } \\
\text { upper } \\
\text { respiratory } \\
\text { and digestive } \\
\text { tracts }\end{array}$} & \multicolumn{2}{|c|}{ Other cancer } & \multicolumn{2}{|c|}{ COPD } & \multicolumn{2}{|c|}{$\begin{array}{l}\text { Other } \\
\text { respiratory }\end{array}$} & \multicolumn{2}{|c|}{$\begin{array}{c}\begin{array}{c}\text { Vascular } \\
\text { disease }\end{array} \\
\end{array}$} & \multicolumn{2}{|c|}{ Cirrhosis } & \multicolumn{2}{|c|}{$\begin{array}{c}\text { Other } \\
\text { medical }\end{array}$} & \multicolumn{2}{|c|}{ Non-medical } & \multicolumn{2}{|c|}{ All causes } & \multicolumn{2}{|c|}{$\begin{array}{l}\text { Person years } \\
(100000 \mathrm{~s})\end{array}$} \\
\hline & First & Second & First $S$ & Second & First & Second & First & Second & First & Second & First & Second & First & Second & First & Second & First & Second & First & Second & First & Second \\
\hline \multicolumn{23}{|l|}{ 35-39: } \\
\hline Current smoker & 0 & NA & 0 & NA & 25 & NA & 0 & NA & 11 & NA & 63 & NA & 10 & NA & 29 & NA & 62 & NA & 202 & NA & $0 \cdot 2649$ & NA \\
\hline \multicolumn{23}{|l|}{$40-44: \$$} \\
\hline Current smoker & 9 & NA & 6 & NA & 33 & NA & 0 & NA & 17 & NA & 147 & NA & 7 & NA & 39 & NA & 96 & NA & 351 & NA & 0.3206 & 0.0008 \\
\hline \multicolumn{14}{|l|}{ 45-49: } & NA & 32 & NA & 67 & NA & 175 & NA & $0 \cdot 1786$ & 0.0025 \\
\hline Current smoker & 33 & 0 & 4 & 62 & 58 & 184 & 7 & 0 & 9 & 0 & 295 & 477 & 10 & 0 & 52 & 128 & 100 & 246 & 568 & 1153 & 0.3118 & 0.0165 \\
\hline $\begin{array}{l}\text { Never smoker } \\
50-54 \text { : }\end{array}$ & 0 & 33 & 0 & 0 & 44 & 29 & 0 & 0 & 0 & 0 & 92 & 240 & 13 & 0 & 7 & 27 & 37 & 86 & 192 & 439 & $0 \cdot 1586$ & 0.0341 \\
\hline \multicolumn{23}{|l|}{ 50-54: } \\
\hline $\begin{array}{l}\text { Never smoker } \\
\text { 55-59: }\end{array}$ & 17 & 0 & 8 & 0 & 92 & 40 & 0 & 0 & 26 & 0 & 292 & 178 & 0 & 13 & 111 & 24 & 83 & 82 & 628 & 392 & $0 \cdot 1222$ & 0.0742 \\
\hline $\begin{array}{l}\text { Current smoker } \\
\text { Never smoker }\end{array}$ & $\begin{array}{r}117 \\
12\end{array}$ & $\begin{array}{r}108 \\
10\end{array}$ & $\begin{array}{r}30 \\
0\end{array}$ & $\begin{array}{l}13 \\
10\end{array}$ & $\begin{array}{r}121 \\
77\end{array}$ & $\begin{array}{l}267 \\
124\end{array}$ & $\begin{array}{r}18 \\
0\end{array}$ & $\begin{array}{l}26 \\
10\end{array}$ & $\begin{array}{l}75 \\
47\end{array}$ & $\begin{array}{l}68 \\
47\end{array}$ & $\begin{array}{r}1018 \\
627\end{array}$ & $\begin{array}{l}997 \\
279\end{array}$ & $\begin{array}{l}39 \\
12\end{array}$ & $\begin{array}{r}96 \\
0\end{array}$ & $\begin{array}{r}101 \\
34\end{array}$ & $\begin{array}{l}66 \\
58\end{array}$ & $\begin{array}{r}105 \\
67\end{array}$ & $\begin{array}{r}106 \\
40\end{array}$ & $\begin{array}{r}1626 \\
876\end{array}$ & $\begin{array}{r}1773 \\
580\end{array}$ & $\begin{array}{l}0 \cdot 2287 \\
0 \cdot 0888\end{array}$ & $\begin{array}{l}0.0738 \\
0.1069\end{array}$ \\
\hline \multicolumn{23}{|l|}{ 60-64: } \\
\hline $\begin{array}{l}\text { Current smoker } \\
\text { Never smoker } \\
\text { 65-69: }\end{array}$ & $\begin{array}{r}265 \\
0\end{array}$ & $\begin{array}{r}283 \\
0\end{array}$ & $\begin{array}{l}58 \\
17\end{array}$ & $\begin{array}{r}140 \\
8\end{array}$ & $\begin{array}{l}354 \\
212\end{array}$ & $\begin{array}{l}360 \\
210\end{array}$ & $\begin{array}{r}84 \\
0\end{array}$ & $\begin{array}{r}141 \\
9\end{array}$ & $\begin{array}{l}85 \\
63\end{array}$ & $\begin{array}{l}11 \\
32\end{array}$ & $\begin{array}{r}1549 \\
989\end{array}$ & $\begin{array}{r}1356 \\
511\end{array}$ & $\begin{array}{r}25 \\
8\end{array}$ & $\begin{array}{r}46 \\
7\end{array}$ & $\begin{array}{l}174 \\
102\end{array}$ & $\begin{array}{r}153 \\
77\end{array}$ & $\begin{array}{r}101 \\
63\end{array}$ & $\begin{array}{l}84 \\
49\end{array}$ & $\begin{array}{l}2696 \\
1448\end{array}$ & $\begin{array}{r}2627 \\
933\end{array}$ & $\begin{array}{l}0 \cdot 1672 \\
0 \cdot 0622\end{array}$ & $\begin{array}{l}0.0925 \\
0.1274\end{array}$ \\
\hline $\begin{array}{l}\text { Current smoker } \\
\text { Never smoker } \\
70-74 \text { : }\end{array}$ & $\begin{array}{r}416 \\
0\end{array}$ & $\begin{array}{r}404 \\
9\end{array}$ & $\begin{array}{r}92 \\
0\end{array}$ & $\begin{array}{r}128 \\
0\end{array}$ & $\begin{array}{l}615 \\
344\end{array}$ & $\begin{array}{l}582 \\
344\end{array}$ & $\begin{array}{c}193 \\
0\end{array}$ & $\begin{array}{r}179 \\
0\end{array}$ & $\begin{array}{l}79 \\
92\end{array}$ & $\begin{array}{l}85 \\
19\end{array}$ & $\begin{array}{l}2455 \\
1250\end{array}$ & $\begin{array}{r}1757 \\
981\end{array}$ & $\begin{array}{r}42 \\
0\end{array}$ & $\begin{array}{r}67 \\
0\end{array}$ & $\begin{array}{l}332 \\
135\end{array}$ & $\begin{array}{l}365 \\
137\end{array}$ & $\begin{array}{l}101 \\
146\end{array}$ & $\begin{array}{l}81 \\
35\end{array}$ & $\begin{array}{l}4325 \\
1959\end{array}$ & $\begin{array}{l}3693 \\
1557\end{array}$ & $\begin{array}{l}0 \cdot 1148 \\
0.0433\end{array}$ & $\begin{array}{l}0.0888 \\
0.1120\end{array}$ \\
\hline $\begin{array}{l}\text { Current smoker } \\
\text { Never smoker } \\
\text { 75-79: }\end{array}$ & $\begin{array}{r}496 \\
38\end{array}$ & $\begin{array}{r}645 \\
25\end{array}$ & $\begin{array}{l}58 \\
37\end{array}$ & $\begin{array}{r}261 \\
0\end{array}$ & $\begin{array}{l}884 \\
671\end{array}$ & $\begin{array}{l}925 \\
597\end{array}$ & $\begin{array}{r}270 \\
0\end{array}$ & $\begin{array}{r}333 \\
25\end{array}$ & $\begin{array}{l}365 \\
215\end{array}$ & $\begin{array}{r}379 \\
63\end{array}$ & $\begin{array}{l}3731 \\
2865\end{array}$ & $\begin{array}{l}2703 \\
1553\end{array}$ & $\begin{array}{l}32 \\
35\end{array}$ & $\begin{array}{l}58 \\
12\end{array}$ & $\begin{array}{c}382 \\
419\end{array}$ & $\begin{array}{l}314 \\
333\end{array}$ & $\begin{array}{r}144 \\
37\end{array}$ & $\begin{array}{r}103 \\
36\end{array}$ & $\begin{array}{l}6158 \\
4351\end{array}$ & $\begin{array}{l}5881 \\
2703\end{array}$ & $\begin{array}{l}0.0683 \\
0.0269\end{array}$ & $\begin{array}{l}0.0692 \\
0.0826\end{array}$ \\
\hline $\begin{array}{l}\text { Current smoker } \\
\text { Never smoker } \\
80-84 \text { : }\end{array}$ & $\begin{array}{l}787 \\
114\end{array}$ & $\begin{array}{r}635 \\
62\end{array}$ & $\begin{array}{r}74 \\
0\end{array}$ & $\begin{array}{r}91 \\
0\end{array}$ & $\begin{array}{r}934 \\
1204\end{array}$ & $\begin{array}{r}1441 \\
833\end{array}$ & $\begin{array}{r}471 \\
58\end{array}$ & $\begin{array}{r}627 \\
58\end{array}$ & $\begin{array}{l}597 \\
232\end{array}$ & $\begin{array}{l}517 \\
314\end{array}$ & $\begin{array}{l}5430 \\
5068\end{array}$ & $\begin{array}{l}4452 \\
2996\end{array}$ & $\begin{array}{l}142 \\
113\end{array}$ & $\begin{array}{l}0 \\
0\end{array}$ & $\begin{array}{l}822 \\
693\end{array}$ & $\begin{array}{r}1002 \\
402\end{array}$ & $\begin{array}{l}102 \\
171\end{array}$ & $\begin{array}{r}235 \\
20\end{array}$ & $\begin{array}{l}9347 \\
7650\end{array}$ & $\begin{array}{l}9194 \\
4796\end{array}$ & $\begin{array}{l}0.0394 \\
0.0174\end{array}$ & $\begin{array}{l}0.0415 \\
0.0515\end{array}$ \\
\hline $\begin{array}{l}\text { Current smoker } \\
\text { Never smoker } \\
\geqslant 85:\end{array}$ & $\begin{array}{r}378 \\
0\end{array}$ & $\begin{array}{r}757 \\
0\end{array}$ & $\begin{array}{r}99 \\
0\end{array}$ & $\begin{array}{l}59 \\
73\end{array}$ & $\begin{array}{l}1964 \\
1243\end{array}$ & $\begin{array}{l}1755 \\
1332\end{array}$ & $\begin{array}{r}534 \\
86\end{array}$ & $\begin{array}{r}867 \\
76\end{array}$ & $\begin{array}{r}1262 \\
799\end{array}$ & $\begin{array}{r}1643 \\
692\end{array}$ & $\begin{array}{l}8388 \\
5187\end{array}$ & $\begin{array}{l}7549 \\
4909\end{array}$ & $\begin{array}{l}0 \\
0\end{array}$ & $\begin{array}{l}0 \\
0\end{array}$ & $\begin{array}{l}1270 \\
1282\end{array}$ & $\begin{array}{l}923 \\
947\end{array}$ & $\begin{array}{l}288 \\
345\end{array}$ & $\begin{array}{l}109 \\
268\end{array}$ & $\begin{array}{r}14178 \\
8950\end{array}$ & $\begin{array}{r}13896 \\
8331\end{array}$ & $\begin{array}{l}0.0205 \\
0.0116\end{array}$ & $\begin{array}{l}0.0183 \\
0.0262\end{array}$ \\
\hline $\begin{array}{l}\text { Current smoker } \\
\text { Never smoker }\end{array}$ & $\begin{array}{r}242 \\
0\end{array}$ & $\begin{array}{l}782 \\
220\end{array}$ & $\begin{array}{r}117 \\
0\end{array}$ & $\begin{array}{r}280 \\
0\end{array}$ & $\begin{array}{l}1215 \\
1688\end{array}$ & $\begin{array}{l}2009 \\
2185\end{array}$ & $\begin{array}{r}1014 \\
0\end{array}$ & $\begin{array}{r}949 \\
74\end{array}$ & $\begin{array}{l}2261 \\
2064\end{array}$ & $\begin{array}{l}3334 \\
1259\end{array}$ & $\begin{array}{l}14998 \\
12808\end{array}$ & $\begin{array}{l}9738 \\
9233\end{array}$ & $\begin{array}{l}0 \\
0\end{array}$ & $\begin{array}{l}0 \\
0\end{array}$ & $\begin{array}{l}3180 \\
2308\end{array}$ & $\begin{array}{l}2939 \\
1783\end{array}$ & $\begin{array}{l}597 \\
480\end{array}$ & $\begin{array}{l}532 \\
511\end{array}$ & $\begin{array}{l}23606 \\
19349\end{array}$ & $\begin{array}{l}20952 \\
15333\end{array}$ & $\begin{array}{l}0.0083 \\
0.0083\end{array}$ & $\begin{array}{l}0.0075 \\
0.0138\end{array}$ \\
\hline
\end{tabular}

In 1971-91, the nine cause specific rates are estimated as $1.02 \times$ the actual rates, but the all causes rate needs no adjustment.

*Current smoker of cigarettes only when smoking habits were last described, or never smoked any form of tobacco regularly.

$\dagger$ Limited data (based on fewer than 25 deaths) in 1951-71; $\ddagger$ Limited data in 1971-91.

SDeaths at age 40-44 in 1971-91: one non-smoker (from "other respiratory" causes) and none of the current cigarette smokers.

$\mathrm{NA}=$ Not applicable; $\mathrm{COPD}=$ chronic obstructive pulmonary disease. 
25 Medical Research Council. Tobacco smoking and cancer of the lung. BMf 1957; i:1523.

D, La Vecchia C, Woutersen R. Alcoholic beverages and cancers of the digestive tract and larynx. In: Verschuren PM, ed. Health cancers of the digestive tract and larynx. In: Verschuren PM, ed.

27 Key T. Diet and smoking related disease: lung cancer and coronary hear disease. Fournal of Tobacco-related Disease (in press).

28 Stamler J, Wentworth D, Vaccaro O, Neaton JD. Diabetes, other risk factors and 12-year cardiovascular mortality for men screened in the multiple ris factor intervention trial. Diabetes Care 1993;16:434-44.

29 National Research Council. Health risks of radon and other intermally deposited alpha-emitters. BEIR IV. Washington, DC: National Academy Press, 1988.

30 Bosch FX, Muñoz N, De Sanjose S, Izarzugaza I, Gili M, Viladiu P, et al. Risk factors for cervical cancer in Colombia and Spain. Int 7 Cancer 1992;52:750-8.

31 Jarvis J. A profile of tobacco smoking. Addiction (in press).

32 Schoenborn CA, Horm J. Negative moods as correlates of smoking and heavie drinking: implications for health promotion. Advance data No 236 Rockville, MD: US Department of Health and Human Services Public Rockville, MD: US

33 Eysenck HJ, Tarrant $M$, Woolf $M$, England L. Smoking and personality $B M 7$ 1960;i:456-60.

34 Thompson RI, Margetts BM, Wood DA, Jackson AA. Cigarette smoking and food and nutrient intakes in relation to coronary heart disease. Nutrition Res $\operatorname{Rev} 1992 ; 5: 131-52$.

35 Margetts BM, Jackson AA. Interactions between people's diet and their smoking habits: the dietary and nutritional survey of British adults. $B M F$ 1993;307:1381-4.

36 Marmot M, Brunner E. Alcohol and cardiovascular disease: the status of the U shaped curve. $B M 7$ 1 $1991 ; 303: 565-8$
37 Doll R, Peto R, Hall E, Wheatley K, Gray R. Mortality in relation to comsumption of alcohol: 13 years' observations on male British doctors. $B M^{\prime}$ 1994;309:911-8.

38 Peto R, Lopez A, Boreham J, Thun M, Heath C. Mortality from tobacco in developed countries: indirect estimation from national vital statistics. Lancet 1992;339:1268-78.

39 Baron JA, Sandler RS. Cigarette smoking and cancer of the large bowel. In: Wald N, Baron J, eds. Smoking and hormone related disorders. Oxford: Oxford University Press, 1990:167-80.

40 Giovannucci E, Rimm EB, Stampfer MJ, Colditz GA, Aschero A, Kearney J, et al. A prospective study of cigarette smoking and risk of colorectal adenoma and colorectal cancer in US men. $\mathcal{F}$ Natl Cancer Inst 1994;86: 183-91.

41 International Agency for Research on Cancer. Alcohol drinking. (Lyons: IARC 1988. IARC Monographs on the Evaluation of Carcinogenic Risks to Humans. Vol 44.)

42 Longnecker MP, Orza MJ, Adams ME, Vioque J, Chalmers C. A metaanalysis of alcoholic beverage consumption in relation to risk of colorectal cancer. Cancer Causes Control 1990;1:59-68.

43 Stellman SD. Influence of cigarette yield on risk of coronary heart disease and chronic obstructive lung disease. In: Zaridze D, Peto R, eds. Tobacco: major international health hazard. Lyons: International Agency for Research on Cancer, 1986. (IARC scientific publication No 74.)

44 Peto R, Lopez A, Boreham J, Heath C, Thun M. Morality from tobacco in developed countries, 1950-2000. Oxford: Oxford University Press, 1994.

45 World Bank. World development report 1993. Investing in health. New York: Oxford University Press, 1993.

(Accepted 20 fune 1994)

\title{
Mortality in relation to consumption of alcohol: 13 years' observations on male British doctors
}

\author{
Richard Doll, Richard Peto, Emma Hall, Keith Wheatley, Richard Gray
}

\section{Abstract}

Objective-To assess the risk of death associated with various patterns of alcohol consumption.

Design-Prospective study of mortality in relation to alcohol drinking habits in 1978 , with causes of death sought over the next 13 years (to 1991).

Subjects-12321 British male doctors born between 1900 and 1930 (mean 1916) who replied to a postal questionnaire in 1978. Those written to in 1978 were the survivors of a long running prospective study of the effects of smoking that had begun in 1951 and was still continuing.

Results-Men were divided on the basis of their response to the 1978 questionnaire into two groups according to whether or not they had ever had any type of vascular disease, diabetes, or "life threatening disease" and into seven groups according to the amount of alcohol they drank. By 1991 almost a third had died. All statistical analyses of mortality were standardised for age, calendar year, and smoking habit. There was a $U$ shaped relation between all cause mortality and the average amount of alcohol reportedly drunk; those who reported drinking 8-14 units of alcohol a week (corresponding to an average of one to two units a day) had the lowest risks. The causes of death were grouped into three main categories: "alcohol augmented" causes $(6 \%$ of all deaths: cirrhosis, liver cancer, upper aerodigestive (mouth, oesophagus, larynx, and pharynx) cancer, alcoholism, poisoning, or injury), ischaemic heart disease (33\% of all deaths), and other causes. The few deaths from alcohol augmented causes showed, at least among regular drinkers, a progressive trend, with the risk increasing with dose. In contrast, the many deaths from ischaemic heart disease showed no significant trend among regular drinkers, but there were significantly lower rates in regular drinkers than in non-drinkers. The aggregate of all other causes showed a U shaped dose-response relation similar to that for all cause mortality. Similar differences persisted irrespective of a history of previous disease, age (under 75 or 75 and older), and period of follow up (first five and last eight years).
Some, but apparently not much, of the excess mortality in non-drinkers could be attributed to the inclusion among them of a small proportion of former drinkers.

Conclusion-The consumption of alcohol appeared to reduce the risk of ischaemic heart disease, largely irrespective of amount. Among regular drinkers mortality from all causes combined increased progressively with amount drunk above 21 units a week. Among British men in middle or older age the consumption of an average of one or two units of alcohol a day is associated with significantly lower all cause mortality than is the consumption of no alcohol, or the consumption of substantial amounts. Above about three units (two American units) of alcohol a day, progressively greater levels of consumption are associated with progressively higher all cause mortality.

\section{Introduction}

It has long been recognised that alcohol can cause death acutely, from poisoning, accidents, or violence, and that long term use can increase the incidence of cirrhosis and of certain types of cancer. In recent years, however, evidence has emerged that the regular consumption of small to moderate amounts of alcohol can also reduce the risk of ischaemic heart disease. ${ }^{1}$ We now need reasonably quantitative information about both the increases and the decreases in mortality that are produced by various patterns of alcohol consumption and about the ways in which these vary with sex, age, and the existence of other predisposing or protective factors.

Reliable quantitative evidence is, however, difficult to obtain. Information about usual drinking habits has to be obtained not from direct measurement but from answers provided by individual people about themselves or their close relatives and friends. Unless the amount usually drunk is close to zero it is intrinsically difficult to describe, and the description is peculiarly liable to bias. For many people, the consumption of alcohol has emotional and moral overtones, and 